\title{
Regin Prenter: A Personal Tribute
}

I met Regin Prenter in his writings before I met him in person. Coming to Denmark in the 1950s I could not help hearing his name. Many of my earliest friends in Denmark had been his students. Even a small acquaintance with his writings made me feel that here was a theologian I could understand, with whom I felt at home. His two books Ordet og Aanden (1952) and Protestantismen $i$ vor Tid (1957) were amongst the first books I struggled through in Danish. Both their content and the clarity of their style provided great incentives to a beginner. In English it is said 'imitation is the sincerest form of flattery', so I adopted the title of the first of these works, with acknowledgement, for a small book of essays which I published in 1963, The Spirit and the Word. But until I looked back in preparing this tribute I had forgotten just how deeply I was influenced by these works, in particular, by their teaching on the relation of faith to prayer, personal and corporate.

What I admired particularly was the ecumenical quality of the writing. Here was a theology which, while rooted in its own tradition, looked beyond the sterile polemics of post-Reformation controversy, and sought for ways of reconciliation in truth. Here, I felt, was an affirmation of faith, which if its accent and vocabulary was distinctly Danish and Lutheran was yet in its substance strangely close to the affirmations which I had found in the theology of the Russian emigration, in writers like Vladimir Lossky and George Florovsky, as well as in representative teachers of my own church from F.D. Maurice to Michael Ramsey. Here, too, was an evident convergence with some of the finest spokesmen of French Catholicism at that time, Yves Congar, for instance, men who were all unwittingly preparing the way for Vatican II. As I made my way into Prenter's Dogmatics I began to see more of the quality and scope of this man. I was particularly struck by the treatment of the presence of Christ's sacrifice in the sacrament of the altar. Here was a point difficult to approach from a Lutheran viewpoint. Prenter treated it with the greatest skill and theological penetration. Above all, I loved the liturgical quality of his writing. Somebody said to me, »You need to sing Prenter's Dogmatics.« Here was a witness to the Una 
Sancta who seemed to me to stand in line with the Grundtvig whose teaching I was just beginning to discover. It was not easy at the beginning - it is not altogether easy now - for a foreigner to find his way through the complexities of Danish Grundtvig interpretation. Prenter's understanding of him encouraged me to feel that my own reading of Grundtvig was not entirely mistaken.

The first meeting in person came in the early 1960s, when I was in Scandinavia travelling with Father Gabriel Hebert, by then an old man making his last visit to his many friends in Sweden and Denmark. Hebert's Scandinavian contacts had meant a great deal to him personally, and through him, to the Church of England. Writers like Aulén, Brilioth, Nygren, became familiar to us through his translations. Hebert loved to tell the story of the visit to Kelham in 1929 of a small group of Danish theological students who arrived by bicycle. They were the founding members of Theologisk Oratorium. They found at Kelham a flourishing religious community, the Society of the Sacred Mission, in charge of a remarkably original theological college. At that moment, Kelham had a certain renown on the continent of Europe. Its founder, H.H. Kelly exemplified a remarkable, if somewhat idiosyncratic kind of Evangelical Catholicity. Dietrich Bonhoeffer, the young Visser t'Hooft, recognised there a significant pointer on the way towards unity. The young Danish visitors were impressed by the way the study of theology at Kelham was rooted in the liturgical and communal life of the place, and at the same time was seeking to grapple with the urgent political, social and cultural issues of the time. It was a vision that linked sacred and profane, tradition and modernity, in very practical ways, and which thought much in terms of interaction and exchange between earth and heaven, human and divine.

It was at this time that I began to find out more about Prenter's friendship with Michael Ramsey which dated from the stay which he made at Lincoln Theological College in 1935, where Ramsey was at that time sub-Warden. This was perhaps the most important of his Anglican friendships. It happened that I visited Prenter at Bedsted in the spring of 1988 and so was able to bring his greetings back to Michael Ramsey when I returned to Oxford and visited him very shortly before his death. It was moving to find how vivid the memories of the two friends were, 
memories of events both comic and serious which had marked their first meeting more than half a century before.

In the course of the years my meetings with Prenter were never numerous but always significant. I regret now that I had so little chance to come into contact with him in his capacity as a university teacher. One thing which I do not forget is his masterly lecture on Grundtvig's Trinitarian theology given during the celebrations in 1983. Still more striking was the sermon on Romans 11:33-36, which he preached in Trinitatis Kirke in Copenhagen that same year on the 200th anniversary of Grundtvig's baptism. In it he recalled not only Grundtvig's baptism at Udby but also his ordination in 1811 in that very church. It was a sermon which gave expression to the awe and joy with which the church acknowledges the depths of the riches of the knowledge of God made known in Jesus Christ, imparted in the Spirit, present in our midst in the celebration of the Eucharist.

\begin{abstract}
»Ham være ære i evighed! Amen « er Paulus's sidste ord om Guds navns hemmelighed. Det er tilbedelsens og lovprisningens højdepunkt. Dermed skal denne gudstjenestes tilbedelse og lovprisning af Guds navn ogsaa ende. Og det skal ske ved alteret, som er al tilbedelses og lovprisnings helligdom paa jorden.
\end{abstract}

Whether in his work as a parish pastor or in his writing as a systematic theologian, as for instance, in his masterly exposition of the thought of Anselm, Guds Virkelighed (1982), one is conscious in Prenter that prayer and theology are never far apart. It would not be inappropriate in his case to use the patristic saying, »he who prays in truth is a theologian, a theologian is one who prays in truth." And all that is wholly God's gift and grace. To quote again from the same sermon:

Ved alteret giver vi Gud hans ære ved at lade ham øse ud til os af sin rigdoms og visdoms og kundskabs dyb, samlet som i en sum og dog gjort saa smaat, at de mindste kan tage imod det, i Jesu paa korset hengivne legeme og blod, rakt os at spise og drikke under brød og vin. 